\title{
口唇裂乳児の術前術後管理について
}

一小児科医の立場から—

保 崎 純 郎*. 吉岡 重 威*

\section{Pre and post-operative care of cleft lip infant from the standpoint of a pediatrician}

\author{
Junro Hosaki* . Shigetake Yoshioka*
}

\section{緒}

\section{言}

近年, 形成手術や小児麻醉の進歩により， 口唇形成手 衍の成績は著しく進歩した. しかし，形成手術を円滑に 行らために, 術前に护ける哺乳指導, 感染予防, さらに その他の合併奇形の早期発見などが重要であることに変 りはない，したがって出生時より手術までの間小児科医 が患児を管理をすることが多い。

以下に東京医科歯科大学医学部小児科に损いて, 本学 龇学部口腔外科にてロ唇形成手術をらける乳睍を入院さ せ，口腔外科医，麻酔医の協力のもとに術前術後管理を 行った成績について，小児科医の立場より報告する.

\section{対}

象

昭和 41 年より昭和 47 年までに小児科に入院し，口腔外 科にて口唇形成手術をらけた460例で，男児291例（63.3 \%)，女児169例（36.7\%）であった。

病型は第 1 表のごとく居顎口蓋裂がもっとも多く,っ いで唇罰裂，口唇裂である.な括，両側口唇裂 101 例の らち58例は小児科入院中に両側の形成手術をらけたので， 手術総件数は518件であった。

成

精

\section{A) 術前管理}

口唇裂乳児はまず小児科外来にて哺乳指導と柴䔃状態 の改善, その他の合併奇形の有無などの治療や恰查を行 い,さらに手術 3 日前に入院させて再び術前恰査を行い 形成手術をらけさせたすすなわち，外来拉よび入院にわ けて術前管理を行った。

\footnotetext{
*東京医科齿科大学医学部小児科学教室（主任：吉田久教授）

*Department of Pediatrics, School of Medicine, Tokyo Medical and Dental University. (Chief : Prof. Hisashi Yoshida)

受付 昭和49年 4 月 1 日
}

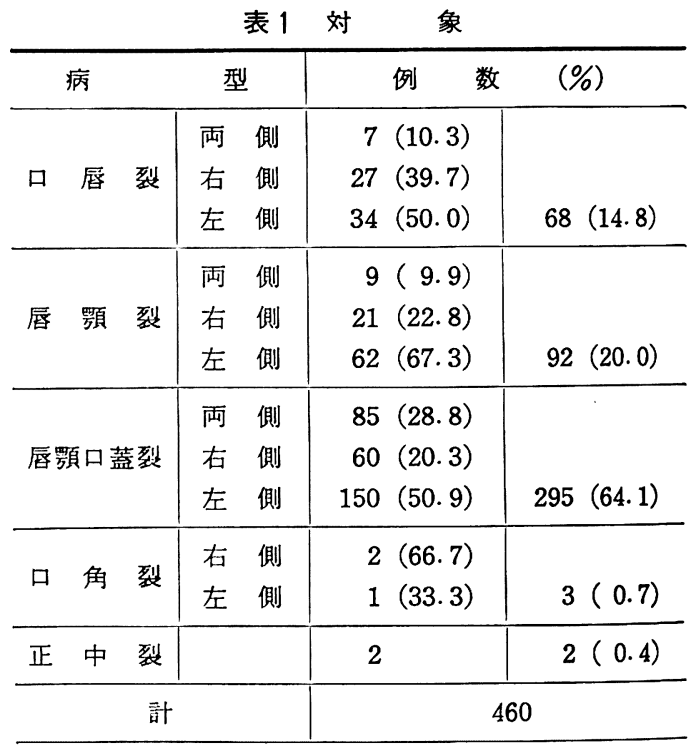

手術件数 518 件（両側手術例 58 件）

\section{I）外来における術前管理}

われわれは過去の経験にもとずいて，つぎのことに重 点を打き管理した.

1）両親に対する精神的助言

2）哺乳指導と栄養状態の改善

3）合併奇形の早期発見とその対策

4) 感染の予防

5）予防接種の問題

6）手術日の決定

1）両親に対する精神的助言：両親とくに母親を精神 的ショックの状態から早く立ち直らせることが必要であ る. そのためには形成手術によってロ辰裂はきれいに形 
表 2 手術時体重

\begin{tabular}{|c|c|c|}
\hline $\begin{array}{l}\text { 漂旉体重に対 } \\
\text { する比率 }\end{array}$ & 口蓋裂合併例 & 口蓋裂非合併例 \\
\hline$+21 \%$ 以上 & $3(0.9)$ & $2(1.2)$ \\
\hline$+11 \% \sim+20 \%$ & $18(5.2)$ & $19(11.2)$ \\
\hline$+10 \% \sim-10 \%$ & $156(44.8)$ & $99(58.2)$ \\
\hline$-11 \% \sim-20 \%$ & $125(35.9)$ & $41(24.1)$ \\
\hline$-21 \%$ 以下 & $46(13.2)$ & $9(5.3)$ \\
\hline 計 & $348(100.0 \%)$ & $170(100.0 \%)$ \\
\hline
\end{tabular}

成できることを母親に説明し，さらに両親以外の祖父母 や親威の人々に哺乳の際に協力するよら指導した.

2）哺乳指導と栄養状態の改善 : その他の奇形や口蓋 裂を伴っている患児では出生直後より哺乳障害のある患 児が多い.すなわち第 2 表のごとく患児の手術時体重を 同月令の標準体重と比較すると, 口蓋裂合併例では栄養 状態の不良な症例（標準体重に比し $-21 \%$ 以下）が多 い.そこで患児の 1 回の哺乳量が少ないこと，また哺乳 時間が長くかかることを教え, 哺乳回数をふやし, 根気 よく授乳するよう指導し，さらに哺乳量や体重測定を定 期的に記録させた、また，症例によっては柔らかい哺乳 瓶の使用, 乳首の穴を大きくすること, そして亀裂部に ハシンソウ高などを貼り哺乳しやすいように指導した ${ }^{12)}$. なおゾンデにより強制栄養を行っている症例に対して は自己哺乳を練習させ，できるたけ早く強制栄養を中止 させ母親自身に授乳させた。

3）合併奇形の早期発見と治療：合併奇形を早期に発 見することは手術予定日を決定する上に重要である．合 併した疾患は第 3 表のごとく，先天奇形としては先天性 心疾患，小頭症，眼奇形などである．とくに先天性心疾 患は早期に発見する必要があるので，初診時にすべての 患児の胸部 X-P 写真, 心電図および血算一式の検查を

表 3 合併した疾患

(対象460例)

\begin{tabular}{|c|c|c|c|}
\hline \multicolumn{3}{|c|}{ 疾 患 名 } & \multirow{2}{*}{$\begin{array}{l}\text { 例 } \\
47\end{array}$} \\
\hline & 養＼cjkstart失＼cjkstart調 & 症 & \\
\hline 喘。 & 息性気管支 & 炎 & 22 \\
\hline 胸 & 腺 肥 大 & 症 & 21 \\
\hline 先 & 天 性 心疾 & 患 & 17 \\
\hline 眼 & 奇 & 形 & 5 \\
\hline 中 & 耳 & 炎 & 4 \\
\hline 小 & 頭 & 症 & 3 \\
\hline$\tau$ & んか & $ん$ & 3 \\
\hline ダ & ウン症候 & 群 & 1 \\
\hline そ & の & 他 & 18 \\
\hline & 热 & 児 & 41 \\
\hline & 計 & & 182 \\
\hline
\end{tabular}

行った。

4）感染の予防：対象が乳児であるので呼吸感染の子 防が重要である. とくに，口蓋裂や先天性心疾患合併例， 扎よび未熟児で出生した症例の呼吸器感染の予防には十 分注意した。また，第 3 表のごとく喘息性気管支炎の症 例も比較的多く，ときには喘鳴のため手術が遅れること があった。な颃感症ではないが遷延性黄疸や乳児肝炎 の症例括よび血色素量 $10 \mathrm{~g} / \mathrm{d} l$ 以下の貧血の症例も早期 に治療した.

5）予防接種の問題：手術時期として一般に 3 カ月〜 5 カ月が適当とされているので，手術時期と予防接種時 期とが重なることが多い，その際シベルクリン反応以外 の BCG 接種, 三種混合ワクチン注射, ポリオ生ワクチ ン服用，種痘接種はすべて術前には中止させた。

6）手術日の決定：われわれは 3 カ月以後で体重が $5 \mathrm{~kg}$ 以上になったら手術を行うよう計画を立てているか。 しかし，手術希望者が多いこと，また小児科で管理する 患児は発育不良の症例が多いなどの理由で，第 4 表のご とく手術時期が予定よりやや遅れている.すなわち， 5 カ月までに $54.8 \% ， 6$ カ月までに $77.2 \%$ が終了した. な抏，6カ月以降に手術を5けた症例のほとんどは合併 奇形や合併疾患のある症例であった。すなわち，先天性 心疾患 17 例中 12 例 $(70.6 \%)$ ，栄養失調症 47 例中 35 例 (74.5\%) がともに6 カ月以後に手術をらけた.

表 4 手術時月令

\begin{tabular}{|c|c|c|}
\hline & 例 数 & 百分率 \\
\hline 3 月半 & 5 & 1.1 \\
\hline 4 月 & 105 & 22.8 \\
\hline 5 月 & 142 & 30.9 \\
\hline 6 月 & 103 & 22.4 \\
\hline 7 月 & 68 & 14.8 \\
\hline 8 月 & 18 & 3.9 \\
\hline 9 月以上 & 19 & 4.1 \\
\hline 計 & 460 & 100.0 \\
\hline
\end{tabular}

以上がわれわれの外来における術前管理であるが，さ らに入院 1 週前に患児を診療し, 合併奇形の診断が不明 な症例, 血色素量 $10 \mathrm{mg} / \mathrm{d} l$ 以下の負血の症例)ならびに 感染症の合併の疑いのある症例は手術を延期させ外来に おいてその治療を行った.

\section{II）入院後の術前管理}

現在の手術予定では入院後 3 日間で血算一式, 検尿一 式, 凝固時間, 出血時間, 肝㭫能, 血清電解質, 胸部 $\mathrm{X}$ - P 写真および心電図検査を行い, その検查結果につ いて麻酔医と相談した後手術をらけさせた，その祭つ ぎの点にとくに重点を拈き管理した.

1）栄養状態について

外来において栄養状態の改善につとめたにもかかわら 
ず，手術時体重が-21\%以下で栄養失調症の症例を 10.8 \%認めた. とくに先天性心疾患17例中 7 例 (41.2\%), 未 熟児で出年した症例41例中15例(36.6\%)の手術時体重が $-21 \%$ 以下の栄養失調症であった.

2）心肺機能について

心肺機能は麻酔の際に重要であるので, 胸部の聴診お よび打診所見, 胸部 X-P写真, そして心電図所見を参 考に心肺機能を検討した. とくに先天性心疾患合併例で は心雑音, 胸部X-P写真および心電図所見を検討し, 先天性心疾患の重症度について麻酔医に連絡した。な据, 喘息性気管支炎などで副腎皮質ホルモン風の服用したこ とのある症例については, 岩井の術前ステロイド投与基 準 ${ }^{5)}$ にもとずき手術前夜より副腎皮質ホルモン剤を投与 した.

\section{3）合併奇形の再確認}

合併奇形のうち先天性心疾患, 小頭症, 肺形成不全の 症例では，手術予定日より $1 \sim 2$ 週前に入院させて奇形 の重症度を再検討し, とくに, 重症奇形の場合 (小頭症 や肺形成不全，チアノーゼを伴ら先天性心疾患など）は あらかじめ麻酔科を受診させその指示をらけた。

\section{4）感染の有無}

対象が乳児であるので感冒, 上気道炎, 気管支炎, 消 化不良症などに䍜患しやすい，したがって，入院患児の 症状，すなわち発熱，咳，喘鳴，嘔吐，下疮なとの症状 に注意し, 手術直前に感染症に䍜患しているかどうかを 診察し，症状によっては手術を延期した。なお，入院前 ないしは入院後に麻疹や水痘に接触し, その疾患の潜伏 期と思われる症例は手術を延期した。

\section{B）術後管理}

手術中および手術直後の管理はすべて麻酔医によって なされているので, 手術を終え回復室から一般病室に戻 ってきた患児を対象にわれわれは管理している，したが って，手術中および手術直後の管理については省略する. 術後管理のらちわれわれがとく重点をおいているのは 手術創の保護, 術後の哺乳そして術後合併症の予防であ る.

\section{1）手術創の保護}

顔面にプロテクターをあて，上腕から手首にかけ硬い フィルムを内臓した抑制衣を着用させ，蝟児扣よび看謢 者が手術創に触れぬようにした。 また, 手術創の消琶お よび清拭は口腔外科医が毎日行った。

\section{2) 術後の哺乳}

手術が順調に終了した場合は, 手術 2 〜 時間後にま ずスポイトで糖水 $80 \mathrm{ml} \sim 100 \mathrm{ml}$ を与え，その後嘔吐な どがなければ $12 \%$ ミルクを 1 回に $100 \mathrm{ml}$ ずつを $2 \sim 3$ 時間ごとに与えた. そして翌日からはスポイドないしは 哺乳瓶で 1 回の哺乳量を増量しながら与えた. その際, 哺乳瓶の乳首やスポイトが手術創に触れぬよらな反対側 から乳首やスポイトをロ腔内に入れて授乳した。ささらに
術後 3 日目からは $15 \%$ ミルクを与えた.なお，母乳栄 養児の場合は，母乳をしぼって哺乳瓶に入れて授乳した。

3）術後合併症の予防

術後合併症の予防を目的として,すべての患児に術後 から抜系終了時まで, Cephaloridine $40 \mathrm{mg} \sim 50 \mathrm{mg} / \mathrm{kg}$ を 2 回に分け連日筋注した。しかし，第 5 表のごとく 12.0\%に術後合併症を認めた. 術後合併症では上気道炎 がもっとも多く，つついてて消化不良症，気管支炎の順で

\section{表 5 術後合併症}

\begin{tabular}{|c|c|c|c|c|c|}
\hline \multicolumn{2}{|c|}{ 疾 } & \multicolumn{2}{|c|}{ 名 } & 例 & 数 \\
\hline 上 & 気 & 道 & 炎 & 26 & \\
\hline 消 & 化 & 不 良 & 症 & 14 & \\
\hline 気 & 管 & 支 & 炎 & 6 & \\
\hline 声 & 带 & 浮 & 腫 & 4 & \\
\hline 尿 & 路 & 感 染 & 症 & 4 & \\
\hline 突 & 発 & 性 発 & 疹 & 2 & \\
\hline け & $w$ & れ & ん & 3 & \\
\hline & & 支 肺 & 炎 & $2^{*}$ & \\
\hline & & 計 & & $\begin{array}{l}61(1 \\
\text { *死 }\end{array}$ & $\begin{array}{l}0 \%) \\
2\end{array}$ \\
\hline
\end{tabular}

あった.な拉，上気道炎，気管支炎，気管支肺炎はその 他の奇形や疾患を合併した症例に多く認めた.すなわち, 先天性心疾患 17 例中 6 例 $(35.3 \%)$, 栄養失調症 47 例中 13 例 $(24.1 \%)$ に上気道炎や気管支炎の術後合併定を認めた. な打気管支肺炎で死亡した 2 例のらち 1 例はReese 症候 群 (両側口唇裂, 右肺形成不全, 白内障), 他の 1 例は 正中裂を伴った Holoprosencephaly（いわゆる無嗅脳症） の症例であった.

\section{考}

按

口唇裂乳児のうちには经口掑取不十分のため，またそ の他の合併奇形のため栄盖状態の不良な症例が多いこと は第 3 表で明らかである．したがって，術前管理とくに 外来に拈ける術前管理が重要である6)。 そこで第一に行 らことは雨親に対する精神的助言とともに哺乳指導であ る.なかでも口蓋裂合併例では体重增加不良の症例が多 いので，ます哺乳指導が必要である．すなわち，出生後 から約 1 カ月の間に母親自身が根気よく授乳するよう指 導することである.とくに，母親自身の授乳を重要視す るのは，乳児院などに預けられていた症例では他の健康 乳児と同様に保育されるので, 哺乳量が減少して体重增 加不良の症例が多いこと，また，手術直前まで他人まか せであったので術後に全く授乳のできない母親がいるか らである，なお，母乳栄養児の場合は上述のよ5に母乳 をしぼって哺乳瓶に入れて与えた.

つぎに口唇裂患児に合侀する奇形は多くみられる 
が7)8)，と〈に手術に影響のある先天性心疾患は早期に発 見する必要がある9!。方し，一回の診察では先天性心 疾患を見逃す場合もあるので，疑わしい症例では繰り返 えし診察して検討し，症例によっては専門医を受診させ ることも必要である。

つぎに先天性心疾患や未熟児で出生した症例では呼吸 器感染に罹患しやすくまた増悪する傾向があるので, 感 冒などに䍜患せぬよら家族に十分指導し，それでも呼吸 器感染に䍜患した場合は早期治療が重要である。また， 口蓋裂合併例では中耳炎に罹患しやすいので，発熱や耳. 漏に注意をする必要がある，なお，喘息性気管支炎の症 例に対する副腎皮質ホルモン剂の投与は，手術に与える 影響を考えできるたけさける必要がある.

手術時期について丹下 ${ }^{10}$ ) $\mathrm{kg})$, 前田 ${ }^{11)}$ は生後10週, 体重10ポンド以上, 藤野 ${ }^{7}$ は 3 カ月以後, 体重 $5 \mathrm{~kg}$ 以上を手術の適応としており,

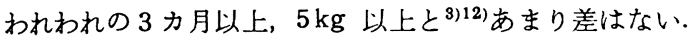
しかし, 栄盖失調症や先天性心疾患, そして喘息性気管 支炎を合併した症例では，上記の条件を満たした上，患 坚の状態が良い時期に行らのが原則である，また，体重 増加が良いから，あるいは家族の希望が強いからといっ て, 生後10週以内に形成手術を行うのは手術効果や術後 管理の点からさけるべきである ${ }^{13)}$.

つきに入院後の術前管理のうち，栄養状態については 外来に拈ける管理が十分であればとくに問題はない。 た，体重増加不良の症例でもその原因が明らかであり， そして心肺機能の異常がなければ手術は可能である。さ らに入院後に環境の変化によって哺乳量が一時的に減少 する場合があり，その際は環境変化によるものか，ある いは感染症の前駆症状であるかを，患児の気嫌，体温そ の他の症状を参考にして鑑別する必要がある，心肺機能 は胸部の聴診と打診, 胸部 X-P写真, 心電図所見を検 討し，手術が可能であるかとららかを決定するが，心肺機 能について小児科医と麻酔医との間に意見の相違がある 際は手術を延期し，問題になった点につき両者で再検討 をする必要がある．なお，副腎皮質ホルモン剤を服用中 ないしは服用したことのある患児では，本剂の服用期間 や服用量を敩重に調查し，麻酔導入時の事故を予防する ため岩井のステロイド投与基準(5にとずき，手術前夜 より副腎皮質ホルモン剂の増量ないしは投与するのが望 ましい.

合併奇型の再確認は外来で十分に検討されてればとく に入院後は問題がない.しかし，手術直前に小児科医が はじめて患児を診察する際はとくに慎重に診察を行って いる. 入院後の感染の有無は，入院患児の症状，すなわ ち, 哺乳量, 気积, 体温, 咳, 嘔吐, 下痢, 喘鳴などに 注意をすれば早期に感染症を発見することが可能である. その際多い疾患は感冒, 突発性発疹, 消化不良症などで ある. また，入院中他の患児に麻疹や水痘が発生した際
はまずその患児と隔崔し，麻疹の場合は ケグロプリン の筋注を行う。しかし，患児が明らかに麻疹や水痘の患 児に接触して潜伏期と思われる症例は手術を延期する必 要がある。

つぎに術後管理において手術創保護の目的で使用され るプロテクターにとくに問題はないが(4), 固定するハン ソウ高で頓部にかぶれを生ずることが多いので，今後さ らに検討の余地がある. 術後はじめての授乳はスポイト あるいは哺乳瓶を使用し, 熟練した看護婦の指導のもと に哺乳させるとよい，また，患児によっては糖水を好ま ず，むしろ白湯を好む場合もあるので，初期に与える水 分は糖水, 白湯のいずれでもよい. なお, 術後 $1 \sim 3$ 日 目までミルクを飲まぬ症例もあり，その際にもミルクを 無理に与えずに白湯や糖水を与えるだけでよい，しかし， 脱水が高度となる場合は輸液により水分を補う必要があ る.

術後合併症は術後に発症した突発性発疹 2 例などを含 くみ $12.0 \%$ に認め, とくに上気道炎, 気管支炎そして 気管支肺炎はその他の疾患を合例した症例に多く認めた。 したがって先天性心疾患や栄養失調症の術後管理はとく に注意し，症例によっては Cephaloridine 以外の抗生物 質の併用や輸液も行った。 なお，消化不良症が流行して いる時期に, 術後合併症として消化不良症が多発する傾 向があったので, 病院内外での小児の流行性疾患につい ての情報を早く知ることも大切である．それと同時に面 会者の政重な制限，そしてその他の入院患児と接触せ奴 よう指導することも感染予防のため重要であっだ). ま た，術後の発熱は他の報告 ${ }^{15)}$ と同じくわれわれも $68 \%$ と同頻度に認めたが，その発熱が手術侵襲による一過珄 発熱か, あるいは感染症, 脱水, その他の要因によるか (16)17), 患児の哺乳量, 気娳, 体温, 嘔吐, 下㢉, 咳な どの症状を観察すれば鑑別は可能である.

以上のことより，われわれが以前から行ってきた ${ }^{18)} 口$ 腔外科医，麻酔医，小児科医によるチーム医療が今後さ らに必要であると思われた。

\section{結語}

1）東京医科歯科大学医学部小児科に入院した後，睏 学部口腔外科に持いて、唇裂形成手術をうけた 460 例の 術前術後管理成績について，小児科医の立場から検討し た。

2）口唇裂乳児は哺乳障害やその他の合併疾患のため 栄養状態不良の症例が多いので, 外来における管理とし ては哺乳指導，合併奇形の早期発見亡感染予防が重要で あった。これらのうち、、）哺乳指導では哺乳ができや すいよらスポイトや柔いプラスチック製の哺乳瓶を使用 し，母親自身に授乳させた，b）先天性心疾患や栄養失 調症を合併した症例では，とくに栄養状態の改善と感染 予防などに注意する必要があった。 
3) 術後合併症は61例 (12.0\%) に認め，上気道炎 (26 例)，消化不良症 (14 例) を主とした。これらの術後合昨 症はその他の疾患を合併していた症例に多く, 術後気管 支肺炎により死亡した 2 例のうち 1 例は Reese 症候群で あり，他の 1 例は Holoprosencephaly であった.

4）以上より口唇裂乳児のらち，a）先天性疾患など 他に何らかの奇形を伴ら症例， b ）栄養状態の不良な症 例， c）喘息性気管支炎を伴う症例などの術前術後管理 にあたっては，小児科医，麻醉医，口腔外科医の密接な 協力が必要と思われた。

本論文の要旨は第25，第26，第27回日本口腔科学会総 会において発表した.

稿を終るに当り，御校閱いたたいた医学部小児科学教 室吉田久教授，御教示と御協力をいただいた歯学部第 1 口腔外科学教室上野正教授に感謝いたします。

$$
\text { 文献 }
$$

1）上芝幸雄：口唇，口蓋裂乳児の吸啜力について. お茶の水医学雑誌 $3: 4931955$.

2) Fogh-Anderson, P. : Preoperative care of cleft palate children in Denmark. Cleft Palate J $70: 5951970$.

3）上野正：象唇，口蓋裂。産婦人科の実際. $17: 945$ 1968.

4）三川宏：最近の小児麻酔(1)。麻酔 20：665 1971 .

5）岩井誠三：小児麻酔について。歯科麻酔研究会会
誌 $3: 11970$.

6）広瀬震一：東京医科歯科大学における鬼展，口蓋 裂の診療（小児科の立場から）。歯界展望 22： 6111963

7）藤野博, 他：現代小児科学大系, 16 巻 A, 中山書 店, 東京, 1969 p 182.

8）藤野博, 他: 口唇, 口蓋裂患児の管理の実漈. 口 科誌 $12: 771963$.

9）岡增一郎，他：口腔外科における心疾患の麻酔. 日本齿科麻䣷学会雑誌 $1: 611973$.

10）丹下一郎：口唇裂，口蓋裂の術前，術後の指導. 小児外科内科 $4: 10091972$.

11）前田華郎, 他：鬼唇，口蓋裂の術前術後管理. 小 児外科内科 $4: 7871972$.

12）上野正：口唇および口腔の奇形. 外科診療 5 : 7381963.

13）久保田康郎：鬼唇, 口蓋裂の形成手術における全 身麻酔の特徵。歯界展望 $22: 6151963$.

14）中村平藏：最新口腔外科学, 医歯薬出版, 東京, 1971 p 72.

15）佐々木元婜，他：わが国における口辰裂口蓋裂児 の麻酔管理の現況調查. 歯科麻酔研究会会誌 2: 271969.

16）高橋敬蔵, 他：術前, 術中, 術後の一般管理. 小 児外科内科 $4: 13311972$.

17）三川宏：最近の小児麻酔(6). 麻酔 $21: 621971$.

18）上野正, 岡達: 東京医科齿科大学に拈け万鬼展, 口蓋裂の診療. 畨界展望 $22: 6091963$. 